\title{
TELAAH KRITIS PRAKTIK PENDISTRIBISUAN DAN MANFAAT ZAKAT FITRAH DI DESA NGADIROJO SOKO PONOROGO TAHUN 2019
}

\author{
Yayuk Ambarwati, Ahmad Royani \\ Institut Agama Islam Riyadlatul Mujahidin (IAIRM) Ngabar Ponorogo \\ Email: royaniahmad963@gmail.com
}

\begin{abstract}
Zakat fitrah is a zakat that must be issued by every individual who is Muslim whose time is related to the holy month of Ramadan. The purpose of zakat fitrah is to purify the soul and fulfill the needs of the needy and poor people on Eid al-Fitr. For the determination of mustahiq must be exactly as specified in Islamic law so that the purpose of zakat fitrah implemented.The practice of managing zakat fitrah in Ngadirojo Village, Sooko District, Ponorogo Regency is left to each mosque in the village. The distribution is carried out by distributing zakat fitrah to people in need and orphanages. But there are still mosques where the distribution of zakat fitrah is distributed evenly by the zakat committee to local residents without looking and considering the economic situation as a mustahiq. In the village there is also one mosque that utilizes zakat fitrah for khataman activities at the end of Ramadan. Why is zakat fitrah in one mosque in Ngadirojo village distributed evenly to local residents without looking at the poor or rich and why does zakat fitrah be used for religious activities? then how about a review of Islamic Law on these practices? This type of research conducted in this study is field research, namely data obtained from direct searches regarding the management of zakat fitrah in Ngadirojo Village, Sooko District, Ponororgo Regency. In getting the data, the compiler made observations and interviews directly to Mudin (zakat fitrah manager in Ngadirojo Village), zakat fitrah committee, and local residents. While the approach that the authors did in this study uses a normative approach, which is to solve the problem using the Qur'an, the hadith, and opinions of the scholars. In analyzing the constituent data using qualitative analysis by analyzing all data collected then described by the inductive method.The practice of the distribution of zakat fitrah in some mosques in Ngadirojo Village distributed to people in need and orphanages is in accordance with Islamic Law. But the distribution of zakat fitrah which is distributed evenly and the use of zakat fitrah for khataman events at the Ar-Rohmah Mosque, Hamlet Wates, Ngadirojo Village cannot be justified in Islamic Law because it does not match what is stated in the Koran at-Taubah verse 60 and not in accordance with the Prophet's hadith.
\end{abstract}

\section{Keywords: Islamic Law, Distribution, Utilization, Zakat Fitrah}

\section{A. PENDAHULUAN}

Sebagai sebuah pranata sosial ekonomi Islam, zakat memiliki berbagai implikasi yang sangat penting antara lain terhadap konsumsi agregat, tabungan nasional dan investasi. Implikasi yang terpenting zakat yaitu dampaknya terhadap konsumsi agregat. Dalam perekonomian Islam dimana zakat diterapkan, maka masyarakat akan terbagi menjadi dua kelompok pendapatan yaitu kelompok pembayar zakat dan penerima zakat. Kelompok masyaraakat wajib zakat (muzakki) akan mentransfer sejumlah proporsi pendapatan mereka ke kelompok masyarakat penerima zakat (mustahiq). ${ }^{1}$

Masyarakat muslim, memahami fikih tidak hanya sebagai aturan formal yang mengatur interaksi antar individu atau kelompok masyarakat, tetapi memiliki pengertian yang lebih luas menyangkut totalitas aturan yang diterapkan dalam segala aspek kehidupan. Karena kedudukannya, sehingga turut menentukan pandangan hidup dan tingkah laku masyarakat muslim, termasuk dalam

\footnotetext{
${ }^{1}$ Yusuf Wibisono, Mengelola Zakat Indonesia (Jakarta: PRENADAMEDIA GROUP, 2015), h. 7.
} 
memahami dan memaknai kewajiban menunaikan zakat. Sehingga dalam masyarakat Islam, ketentuan zakat sudah mulai terlupakan dan disempitkan artinya. Zakat seolah-olah hanya merupakan kewajiban individu dan dilaksanakan dalam rangka menggugurkan kewajiban individu terhadap perintah Allah SWT. Sehingga zakat menjadi apa yang sering disebut sebagai ibadah mahdhah individu kaum muslimin. ${ }^{2}$

Zakat adalah rukun Islam ketiga yang berupa sejumlah harta tertentu yang terselip dalam kekayaan yang dimiliki secara riil oleh setiap pribadi muslim yang diwajibkan oleh Allah SWT untuk diberikan kepada orang-orang yang berhak atas itu setelah mencapai nisab dan haul, guna membersihkan harta kekayaan dan menyucikan jiwa pemiliknya. ${ }^{3}$

Zakat dalam al-Qur'an dan al-Hadits kadang-kadang disebut dengan sedekah, seperti firman Allah SWT dalam surat At-Taubah ayat 103 :

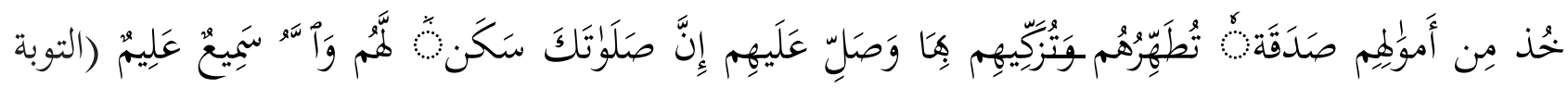

"Ambillah zakat dari sebagian harta mereka, dengan zakat itu kamu membersihkan dan mensucikan mereka dan mendoalah untuk mereka. Sesungguhnya doa kamu itu (menjadi) ketenteraman jiwa bagi mereka. Dan Allah Maha Mendengar lagi Maha Mengetahui”. 4

Zakat fitrah adalah zakat pribadi yang harus dikeluarkan pada hari raya 'idul Fitri sebelum sholat 'Ied. ${ }^{5}$ Pada prinsipnya, barang yang dibayarkan untuk zakat fitrah adalah berupa makanan pokok penduduk suatu daerah, seperti beras, gandum, sagu, dan jagung. Untuk masing-masing jiwa yaitu 1 sha' atau setara dengan 4 mud. Dalam penyaluran zakat fitrah harus disalurkan pada orangorang yang tepat, sesuai dengan ketentuan hukum Islam yang terdapat dalam al-Qur'an surat AtTaubat ayat 60 :

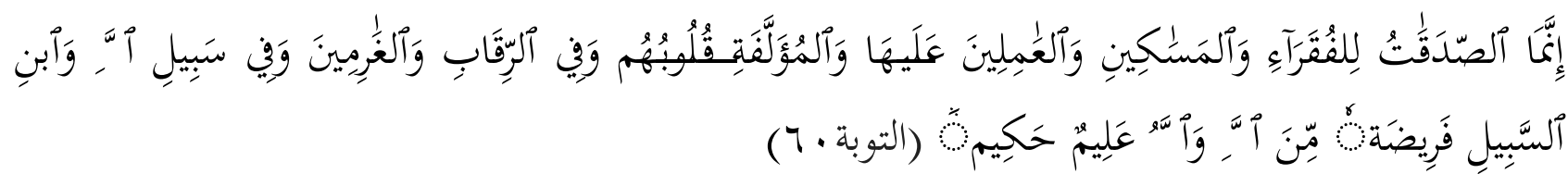

"Sesungguhnya zakat-zakat itu, hanyalah untuk orang-orang fakir, orang-orang miskin, penguruspengurus zakat, para mu'allaf yang dibujuk hatinya, untuk (memerdekakan) budak, orang-orang yang berhutang, untuk jalan Allah dan untuk mereka yang sedang dalam perjalanan, sebagai suatu ketetapan yang diwajibkan Allah, dan Allah Maha Mengetahui lagi Maha Bijaksana”.

Penjelasan ayat al Qur'an di atas menyebutkan bahwa terdapat delapan golongan penerima zakat (mustahiq) yaitu faqir, miskin, amil zakat (pengurus zakat), muallaf (orang yang baru masuk Islam), ibnu sabil (orang dalam perjalanan), riqab (budak/orang yang merdeka), gharim (orang yang berhutang), dan sabilillah (orang yang berjuang dijalan Allah). ${ }^{7}$ Pelaksanaan pengumpulan dan pendistribusian zakat fitrah menjadi kewenangan amil zakat, sehingga praktik zakat berjalan dengan baik dan sesuai tata cara (hitung dan kadar) yang benar dan mustahik juga menerima sesuai kondisi dan kapasitasnya sebagai seorang atau golongan yang berhak menerima zakat fitrah.

\footnotetext{
${ }^{2}$ Subki Risya, Zakat Untuk Pengentasan Kemiskinan (Jakarta: PP. LAZIS NU, 2009), h. 3-4.

${ }^{3}$ Cholid Fadlullah, Mengenal Hukum ZIS (Zakat dan Infak/Sedekah) Dan Pengamalannya Di DKI Jakarta (DKI Jakarta: BAZIS DKI Jakarta, 1993), h. 5.

${ }^{4}$ Departemen Agama RI, Al-Qur'an Dan Terjemahnya Al-Hikmah (Bandung: CV Diponegoro, 2006), h. 203.

${ }^{5}$ Cholid, Mengenal Hukum, h. 10.

${ }^{6}$ Departemen, Al-Qur'an Dan Terjemahnya, h. 196.

${ }^{7}$ Najib Hamid dan Hery Siswondo, Pendidikan Al-Islam Untuk SMA/SMK/MA Muhammadiyah kelas $x$ (Surabaya: Majelis Dikdasmen PWM Jatim, 2013), h. 150-151.
} 
Orang kaya adalah termasuk orang-orang yang tidak boleh menerima zakat. Hal tersebut dikarenakan zakat diambil dari orang-orang yang kaya dan diperuntukkan kepada fuqara' dan masakin ( mustahiq). Sesuai juga dengan sabda Rasulullah SAW :

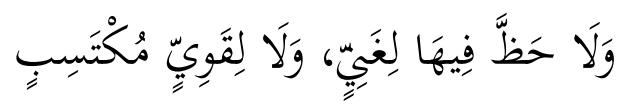

"Tidak ada hak zakat untuk orang kaya, maupun orang yang masih kuat bekerja".

Terkait dengan pembahasan di atas, unit pengelola zakat fitrah di desa Ngadirojo Kecamatan Sooko Kabupaten Ponorogo pada tahun 2019, sebagian besar penduduknya mengeluarkan zakat secara langsung melalui unit pengelola zakat fitrah di masjid setempat tanpa ada paksaan dari pihak manapun. Sistem pengumpulan zakat fitrah di desa Ngadirojo ini dilaksanaan oleh seluruh warga dengan mengumpulkan kepada unit pengelola zakat fitrah di masing-masing masjid. Pengumpulan zakat fitrah dilaksanakan pada malam hari, 2 hari sebelum hari raya 'idul fitri.

Zakat fitrah yang telah terkumpul dari warga dikumpul menjadi satu dan dihitung jumlahnya. Setelah terhitung jumlah zakat fitrah yang terkumpul, unit pengelola zakat fitrah melakukan pembagian, dalam pembagian zakat fitrah di desa Ngadirojo ini semua warga mendapat bagian dari zakat fitrah tersebut, diantaranya fuqara', masakin, pengurus unit pengelola zakat, dan orang kaya sebagaimana kebiasaan yang telah berlaku selama ini. ${ }^{9}$ Pembagian zakat fitrah tersebut sepintas cukup adil untuk semuanya, baik bagi masyarakat maupun unit pengelola zakat fitrah, tetapi dengan pendistribusian secara merata tersebut akan mengurangi hak mustahiq terhadap zakat fitrah. Karena mereka yang dianggap mampu dan kaya tetap mendapat bagian yang sama. Pembagian zakat fitrah tidak berjalan sebagaimana mestinya menurut ketentuan hukum Islam . Padahal dalam surat AtTaubat ayat 60 sudah dijelaskan siapa saja yang berhak menerima zakat fitrah. Pelaksanan pembagian zakat fitrah seperti inilah menurut ketentuan hukum Islam belum dapat dibenarkan.

Tulisan artikel ini selanjutnya akan mengkupas tuntas pelaksanaan pendistribusian zakat fitrah, dan penerima zakat fitrah, pelaksanaan kerja unit pengelola zakat fitrah, dan pemanfaatan zakat fitrah digunakan untuk makan bersama di acara khataman pada akhir ramadhan.

\section{B. PEMBAHASAN}

\section{Praktik Pendistribusian Zakat Fitrah}

Penyaluran dan pendistribusian zakat fitrah yang telah terkumpul dibagikan kepada mustahiq (orang-orang yang berhak menerima zakat) sesuai dengan yang disebutkan dalam Al-Qur'an surat At-Taubah ayat 60. "Sesungguhnya zakat-zakat itu, hanyalah untuk orang-orang fakir, orang-orang miskin, pengurus-pengurus zakat, para mu'allaf yang dibujuk hatinya, untuk (memerdekakan) budak, orangorang yang berhutang, untuk jalan Allah dan untuk mereka yang sedang dalam perjalanan, sebagai suatu ketetapan yang diwajibkan Allah, dan Allah Maha Mengetahui lagi Maha Bijaksana". ${ }^{10}$

Sebagaimana yang dijelaskan oleh unit pengelola zakat yang mengurusi zakat fitrah di desa Ngadirojo bahwa zakat fitrah di desa Ngadirojo untuk penyaluran dan pendistribusian diserahkan kepada masing-masing masjid di desa tersebut yaitu masing-masing Masjid Ar-Rohmah dukuh Buyut, Masjid An-Nur dukuh Buyut, Masjid Darul Arqom dukuh Buyut, Masjid Al-Falah dukuh Buyut, Masjid Baitul Amanah, Masjid Hudatul Hikmah dukuh Ploso, Masjid Nuroh Abal Khoir dukuh Karangrejo, Masjid Pinggirsari dukuh Karangrejo, dan Masjid Al-Hasan dukuh Ngadirojo penyaluran dan pendistribusian dibagikan kepada masyarakat yang membutuhkan serta dibagikan kepada panti asuhan Ar-Fahrudin dan panti asuhan Fathul Muna. Sesuai keterangan di atas untuk

\footnotetext{
${ }^{8}$ HR. Nasa'I 2598, Abu Daud 1633, dan dishahihkan Al-Albani.

${ }^{9}$ Ariska Sipaul Jannah, Wawancara, di rumah, 17 Oktober 2019, pukul 20.00 WIB.

${ }^{10}$ Departemen, Al-Qur'an Dan Terjemahnya, h. 196.
} 
penyaluran dan pendistribusian zakat fitrah yang dilakukan di masjid yang disebutkan di atas sudah sesuai dengan ketentuan hukum Islam.

Sedangakan di Masjid Ar-Rohmah, dukuh Wates penyaluran dan pendistribusian berbeda dengan masjid lainnya. Pendistribusian di masjid ini dilakukan secara merata ke seluruh penduduk kaya maupun miskin, kepada semua masyarakat sekitar masjid dan juga diberikan kepada masyarakat jama'ah masjid lain. Untuk jumlah zakat fitrah yang didapatkan setiap orang bisa saja lebih dari satu bagian zakat fitrah. ${ }^{11}$ Penyaluran dan pendistribusian zakat fitrah secara merata yang dilakukan di Masjid Ar-Rohmah, dukuh Wates belum sesuai dengan ketentuan dalam hukum Islam. Penyaluran dan pendistribusian zakat fitrah secara merata yang dilakukan di masjid tersebut mengurangi hak para mustahiq terutama fuqara' dan masakin. Meskipun apabila dilihat dari segi sosial kemasyarakatan dianggap adil dan cocok untuk dilakukan. ${ }^{12}$

Dalam hal pendistribusian zakat fuqara' dan masakin adalah mereka yang berhajat yang tidak mempunyai kifayahnya. Lawan mereka ialah orang kaya, yaitu orang mempunyai kecukupan. Telah diketahui, bahwa kadar kekayaan yang dianggap seseorang disebut kaya ialah kadar nishab yang lebih dari keperluan pokok bagi diri, anak isteri, dari makan dan minum, pakaian, tempat tinggal, kendaraan, alat bekerja dan lain-lain yang sungguh-sungguh diperlukan. Maka semua orang yang tidak mempunyai milik tersebut itu berhak menerima zakat. ${ }^{13}$

Memperhatikan sistem perekonomian dalam Islam, zakat juga memiliki dampak stabilisasi terhadap perekonomian melalui jalur tabungan dan investasi. Dimana zakat diterapkan riba dilarang, pembayaran zakat kepada kelompok penerima zakat adalah sebuah transfer kekayaan yang dominan dalam perekonomian Islam, sehingga zakat memiliki dampak sosial yang luar biasa sebagai tabungan dan investasi. Dapat juga zakat digunakan sebagai sarana pembangunan perekonomian bagi kelompok penerimanya (mustahiq). Dalam sistem perekonomian Islam, perlindungan ekonomi pada kelompok penerima zakat (mustahiq), memiliki banyak instrument yang antara lain zakat fitrah, zakat mal, infak, dan wakaf. $^{14}$

\section{Pemanfaatan Zakat Fitrah}

Rosulullah SAW memerintah agar hasil zakat fitrah yang dikumpulkan agar diserahkan kepada orang-orang fuqara' dan masakin (mustahiq) sebelum dilaksanakan sholat 'idul Fitri, supaya di hari itu semua orang baik yang kaya maupun miskin dapat merayakan 'idul Fitri dengan gembira dan bahagia tanpa ada yang masih meminta-minta karena belum mempunyai makanan yang cukup pada hari tersebut.

Dalam hal penggunaan dana zakat para ulama berbeda pendapat. Perbedaan pendapat ini bersumber dari perbedaan penafsiran tentang kata "fii sabilillah". Boleh menggunakan dana zakat untuk masjid ketika darurat. Hukum asalnya tidak boleh menggunakan dana zakat untuk masjid. Hanya saja, zakat dapat digunakan untuk membangun masjid ketika tidak ada dana lain selain dana zakat, sedangkan masjid sangat kebutuhan dana zakat tersebut, dan kebutuhan fakir miskin terdekat telah terpenuhi. Masjid tidak hanya berfungsi sebagai tempat shalat saja tapi juga berfungsi untuk menegakkan dan memperjuangkan agama Allah. Masjid harus berfungsi sebagai tempat shalat dan pusat dakwah Islam untuk menolong dan memperjuangkan agama Allah. Ketentuan-ketentuan itu hanya dapat terpenuhi pada daerah-daerah terpencil dan miskin atau pada negara-negara yang muslimnya minoritas. ${ }^{15}$

Penjelasan dari salah seorang sumber informasi di desa Ngadirojo Soko, sebagaimana yang telah disampaikan bahwa zakat fitrah sebagian dimanfaatkan untuk makan bersama pada kegiatan khataman. Hal itu sudah menjadi kebiasaan jama'ah Masjid Ar-Rohman dukuh Wates, desa

${ }^{11}$ Bapak Choirul Hadi, Modin. Wawancara i, 30 September 2019, Pukul 18.30 WIB.

12 Ariska Sipaul Jannah, Wawancara, 17 Oktober 2019, Pukul 20.00 WIB.

${ }^{13}$ Hasbi Ash Shiddieqy, Pedoman Zakat (Semarang: PT. PUSTAKA RIZQI PUTRA, 2009), h. 146.

${ }^{14}$ Yusuf Wibisono, Mengelola Zakat Indonesia, h. 17-18.

15 https://zakat.or.id/hukum-penggunaan-dana-zakat-untuk-pembangunan-masjid/ diakses pada senin, 23 september 2019 pukul 20.06 wib. 
Ngadirojo, maka hal itu diperbolehkan menurut hukum Islam karena sudah menjadi kebiasaan (hukum adat). ${ }^{16}$

Keterangan yang disampaikan oleh unit pengelola zakat fitrah di masjid tersebut beliau menganggap tidak apa-apa kalau zakat fitrah digunakan untuk makan bersama pada kegiatan khataman, lagi pula ini sudah menjadi kesepakatan bersama dan sudah merupakan adat yang dari dulu dilaksanakan di masjid tersebut. Yang menjadi permasalahan di sini apakah memanfaatkan zakat fitrah untuk memberi makan bersama pada kegiatan khataman diakhir ramadhan diperbolehkan dalam hukum Islam. Sebenarnya di dalam Hukum Islam zakat fitrah harus didistribusikan sampai habis kepada yang berhak tanpa menyisakannya. Seperti juga yang telah dijelaskan di atas zakat fitrah boleh dimanfaatkan hanya untuk kepentingan darurat. Seperti ketika tidak ada dana lain untuk membangun masjid selain dana zakat, maka dana zakat dapat digunakan untuk pembangunan masjid. Dari keterangan tersebut di atas dapat diketahui bahwa pemanfaatan zakat fitrah untuk keperluan makan bersama pada kegiatan khataman di akhir ramadhan yang dilaksanakan di desa Ngadirojo belum sesuai dengan ketentuan hukum Islam.

Dalam perspektif ekonomi Islam, sebagai sebuah risalah paripurna dan ideologi hidup, Islam sangat memperhatikan masalah kemiskinan. Bahkan kemiskinan dipandang sebagai salah satu ancaman terbesar bagi ke imanan seseorang. Kemiskinan sepenuhnya dipandang sebagai masalah struktural karena Allah menjamin rizqi setiap makhluk yang telah, sedang, dan akan diciptakan dan pada saat yang sama Islam telah menutup peluang bagi kemiskinan kultural dengan memberi kewajiban mencari nafkah bagi setiap individu. Setiap makhluk dijamin memiliki rizqinya masingmasing dan merka tidak akan kelaparan. ${ }^{17}$ Dari paparan tersebut dapat diketahui bahwa Allah tidak menciptakan kemiskinan bagi makhluknya, tetapi justru memberikan kecukupan dengan cara yang diberikan-Nya yaitu kewajiban mencari nafkah bagi semua individu termasuk di dalamnya kewajiban untuk membayar zakat fitrah disetiap akhir puasa ramadhan. Zakat fitrah juga dapat dipandang sebagai sebuah solusi atau jalan keluar untuk mengatasi kemiskinan, zakat fitrah dapat dijadikan sebagai modal usaha atau investasi.

\section{PENUTUP}

Pendistribusian zakat fitrah di desa Ngadirojo sebagian masjid sudah sesuai dengan ketentuan hukum Islam yaitu sebagaimana yang dilakukan di Masjid Ar-Rohmah dukuh Buyut, Masjid AnNur dukuh Buyut, Masjid Darul Arqom dukuh Buyut, Masjid Al-Falah dukuh Buyut, Masjid Baitul Amanah, Masjid Hudatul Hikmah dukuh Ploso, Masjid Nuroh Abal Khoir dukuh Karangrejo, Masjid Pinggirsari dukuh Karangrejo, dan Masjid Al-Hasan dukuh Ngadirojo penyaluran dan pendistribusian dibagikan kepada masyarakat yang membutuhkan, dan dibagikan kepada panti asuhan Ar-Fahrudin, dan panti asuhan Fathul Muna. Meskipun pendistibusian zakat fitrah di masjid Ar-Rohmah dukuh Wates belum sesuai dengan ketentuan hukum Islam karena dalam penyaluran dan pendistribusian yang dilakukan secara merata kepada yang kaya dan miskin.

Pemanfaatan zakat fitrah di desa Ngadirojo Kecamatan Sooko, Kabupaten Ponorogo yaitu zakat fitrah untuk keperluan makan bersama pada kebiasaan kegiatan khataman di akhir ramadhan di desa Ngadirojo Kecamatan Sooko Kabupaten Ponorogo, belum sesuai dengan ketentuan hukum Islam walaupun ditinjau dari sisi adat kebiasaan diperbolehkan.

\section{Daftar Pustaka}

Ash Shiddieqy, Hasbi. 2009. Pedoman Zakat. Semarang: PT. Pustaka Rizy Putra.

Departemen Agama RI. 2006. Al-Qur'an Dan Terjemahnya Al-Hikmah. Bandung: CV Diponegoro.

Fadlullah, Cholid. 1993. Mengenal Hukum ZIS (Zakat dan Infak/Sedekah) Dan Pengamalannya Di DKI Jakarta. DKI Jakarta: BAZIS DKI Jakarta.

${ }^{16}$ Bapak Sibun, Panitia Pengurus Zakat. Wawancara, 13 Oktober 2019, Pukul 15.00 WIB.

${ }^{17}$ Yusuf Wibisono, Mengelola Zakat Indonesia, h. 22-23. 
Hamid, Najib, dan Siswondo, Hery. 2013. Pendidikan Al-Islam Untuk SMA/SMK/MA Muhammadiyah kelas $x$. Surabaya: Majelis Dikdasmen PWM Jatim.

HR. Nasa'I 2598, Abu Daud 1633, dan dishahihkan Al-Albani.

https://zakat.or.id/hukum-penggunaan-dana-zakat-untuk-pembangunan-masjid// diakses pada senin, 23 september 2019 pukul 20.06 wib.

Risya, Subki. 2009. Zakat Untuk Pengentasan Kemiskinan.Jakarta: PP. Laziz NU.

Wibisono, Yusuf. 2015. Mengelola Zakat Indonesia. Jakarta: Prenada Media Group. 
